\title{
Pembuatan dan Karakterisasi Sensor Amonia Berbasis Bending Fiber Optic
}

\author{
Chandra Pratiwi $^{(1)}$, Gandi Sugandi ${ }^{(2)}$ Junaidi $^{(1)}$ \\ (1) Jurusan Fisika, FMIPA, Universitas Lampung, \\ Jl.Prof. Dr. Soemantri Brojonegoro No.1 Gedung Meneng Bandar Lampung 35145 \\ ${ }^{(2)}$ PPET-LIPI, Bandung, Jawa Barat, 40135 \\ Email: chandrapratiwi93@gmail.com,gandi511@yahoo.com, \\ junaidi1982@fmipa.unila.ac.id (corresponding author)
}

Diterima (25 April 2018), direvisi (11 Mei 2018)

\begin{abstract}
This research was approved optical fiber bending sensors with good characterization and variations in the concentration of ammonia solution. This research uses experimental methods in the laboratory. The technique was done by stripping multimode optical fibers (cladding measuring $125 \mu \mathrm{m}$ and core $62 \mu \mathrm{m}$ ) which is exfoliated cladding then replaced by polydimethylsiloxane (PDMS) and bending with the combustion process. The concentration of ammonia solution used in this research varies from 1-10\%. Measurement of fiber optic sensors using optical power meter (OPM) with a wavelength of $1310 \mathrm{~nm}$ and $1550 \mathrm{~nm}$, and light source (LS) at a frequency of $0 \mathrm{~Hz}, 270 \mathrm{~Hz}, 1000 \mathrm{~Hz}$, and $2000 \mathrm{~Hz}$. The result showed that ammonia solution caused instability in light intensity. However, the higher the frequency of light. The lower of the intensity with the difference in intensity produced is very small.
\end{abstract}

Keywords: ammonia, bending, cladding, optical fiber, polydimethylsiloxane (PDMS).

\begin{abstract}
Abstrak. Penelitian ini bertujuan untuk menghasilkan sensor berbasis bending serat optik dengan karakterisasi yang baik dan variasi konsentrasi larutan amonia. Penelitian ini menggunakan metode eksperimental di laboratorium. Teknik yang dilakukan adalah dengan menggunakan serat optik multimode (cladding berukuran $125 \mu \mathrm{m}$ dan core $62 \mu \mathrm{m}$ ) yang dikelupas slongsongnya (cladding) lalu digantikan oleh polydimethylsiloxane (PDMS) dan dibengkokan (bending) dengan proses pembakaran. Konsentrasi larutan amonia yang digunakan pada penelitian ini bervariasi yaitu 1-10\%. Pengukuran sensor serat optik menggunakan optical power meter (OPM) dengan panjang gelombang $1310 \mathrm{~nm}$ dan $1550 \mathrm{~nm}$ serta light source (LS) pada frekuensi $0 \mathrm{~Hz}, 270 \mathrm{~Hz}$, $1000 \mathrm{~Hz}$, dan $2000 \mathrm{~Hz}$. Hasil penelitian menunjukkan bahwa larutan amonia menyebabkan ketidakstabilan intensitas cahaya. Semakin tinggi frekuensi cahaya yang mengenai sensor, maka semakin rendah intensitas yang dihasilkan dengan perbedaan intensitas sangat kecil.
\end{abstract}

Kata kunci: amonia, bending, cladding, polydimethylsiloxane (PDMS), serat optik.

\section{PENDAHULUAN}

Karakteristik bahan serat optik sangat berpengaruh dalam transmisi sinyal pada serat optik tersebut. Pemantulan dan pembiasan sinyal di dalam serat optik tergantung pada indeks bias bahan yang dipakai dalam serat optik tersebut. Attenuasi (redaman) juga menjadi masalah tersendiri dalam penyaluran sinyal. Bentuk redaman yang sering terjadi ketika proses instalasi kabel adalah bending (pembengkokan). Serat optik mengalami redaman/rugi-rugi sinyal ketika dibengkokan pada jari-jari tertentu. Sinyal yang teredam di tengah perjalanan menuju penerima menyebabkan 
penurunan kualitas sinyal yang diterima oleh konsumen ketika menggunakan jasa[1]. Sensor serat optik dibagi atas tiga tipe, yaitu sensor serat optik ekstrinsik, sensor serat optik instrinsik dan sensor evanescent. Sensor evanescent dibuat dengan mengupas selongsong (cladding) asli serat optik dan diganti dengan material yang lain sehingga nilai indeks biasnya berubah.

Penelitian ini mempelajari karakteristik rugi-rugi serat optik dengan serat optik yang ditinjau adalah serat optik yang telah dikelupas selongsongnya (sensor serat optik berdasarkan efek gelombang evanescent). Penelitian dilakukan dengan memvariasikan konsentrasi larutan amonia dimana selongsong pengganti yang dipakai adalah Polydimethylsiloxane (PDMS) tanpa pewarna dan PDMS yang diberi pewarna Bromocressol-Purple dye. Selain sebagai pengganti selongsong pada serat optik, PDMS juga sebagai bahan yang sensitif terhadap amonia.

Serat optik merupakan media transmisi atau pandu gelombang cahaya berbentuk silinder yang dikembangkan diakhir tahun 1960-an sebagai jawaban atas perkembangan sistem komunikasi yang semakin lama membutuhkan bandwidth yang besar dengan laju transmisi yang tinggi. Serat optik terbuat dari bahan dielektrik berbentuk seperti kaca. Di dalam serat inilah energi cahaya yang dibangkitkan oleh sumber cahaya disalurkan sehingga dapat diterima di ujung unit penerima[2]. Rugi-rugi/loss pada serat optik diakibatkan karena terjadinya kebocoran atau karena kurangnya kejernihan bahan serat optik.

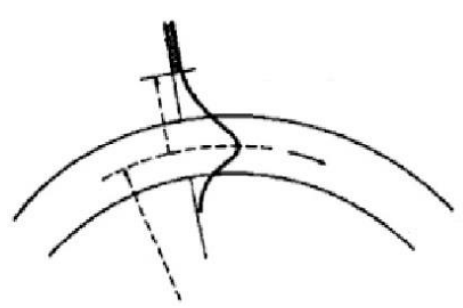

Gambar 1. Pembengkokan makro pada serat optik

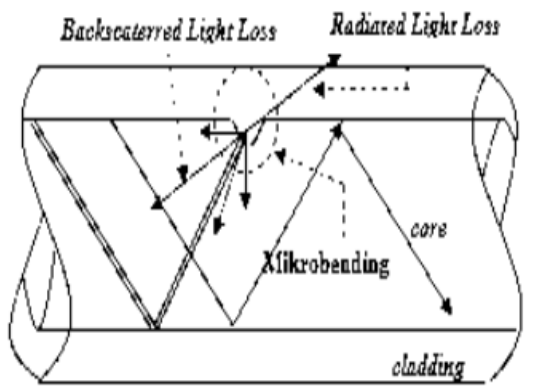

Gambar 2. Skema pembengkokan mikro

Besaran pelemahan energi yang dibawa oleh serat optik dinyatakan dalam deci-Bell (dB). Faktor utama penyebab pelemahan ini adalah: serapaan, hamburan, dan bending losses. Bending adalah pembengkokan yang menyebabkan cahaya yang merambat pada serat optik menyimpang dari arah transmisinya semula dan lenyap. Pembengkokan ini menyebabkan rugi-rugi yang dibedakan menjadi dua macam yaitu rugi-rugi pembengkokan makro dan mikro.

Rugi-rugi pembengkokan makro terjadi ketika cahaya melalui serat optik yang dibengkokan sehingga membentuk kelengkungan dengan radius yang lebih besar dari radius serat optik, seperti terlihat pada Gambar 1. Jari-jari kritis atau critical radius adalah jari-jari bengkokan mendekati pertambahan nilai rugi-rugi yang cepat. Jarijari kritis pada multimode dirumuskan dengan Persamaan (1) [3]:

$$
R_{c}=\frac{3 n_{1}^{2} \lambda}{4 \pi\left[n_{1}^{2}-n_{2}^{2}\right]^{1 / 2}}
$$

Ketika dibengkokkan, serat optik mengalami stress. Stress ini mengakibatkan indeks bias bahan serat optik berubah menurut formulasi yang diperoleh secara eksperimen. Selanjutnya pembengkokan mikro. Pada prinsipnya pembengkokan mikro menimbulkan efek yang sama dengan pembengkokan makro, hanya saja ukuran dan penyebab terjadinya berbeda. Jari-jari lekukan yang timbul dalam kasus ini adalah sama dengan atau kurang dari garis tengah serat optik yang hanya terdiri dari inti, buffer primer, dan jaket. 
Permasalahan pembengkokan mikro pada umumnya timbul di dalam proses pabrikasi. Salah satu penyebabnya adalah perbedaan laju pemuaian dan penyusutan antar serat optik dan pelindung-pelindung luarnya. Peristiwa serat optik akibat pembengkokan makro dapat dilihat pada Gambar 2.

\section{METODE PENELITIAN}

Metodologi penelitian yang digunakan adalah metode eksperimental di laboratorium. Penelitian ini meliputi absorption loss serat optik dengan metode pengelupasan slongsong sampai ke inti serat optik dan slongsong digantikan dengan PDMS.

PDMS merupakan jenis polimer hibrid yang terdiri dari rantai utama (backbone) $\mathrm{Si}$ $\mathrm{O}-\mathrm{Si}$ dan memiliki struktur kimia $\left(\mathrm{CH}_{3}\right)_{3} \mathrm{SiO}-\left[\mathrm{Si}\left(\mathrm{CH}_{3}\right)_{2} \mathrm{O}\right] \mathrm{N}-\mathrm{Si}\left(\mathrm{CH}_{3}\right)_{3}$.

Polimer hybrid merupakan jenis polimer yang unit perulangannya terdiri dari kombinasi molekul organik dan anorganik. PDMS memiliki karakteristik inert secara kimia, transparan, hidrofobik, nonabsorable (tidak menyerap zat lain), dan pada rentang cahaya tampak memiliki nilai transmitasi mencapai $100 \%$ sehingga semua cahaya tampak dapat ditransmisikan sepenuhnya [4]. Daerah yang terkelupas dan telah diselimuti PDMS akan digunakan sebagai daerah perubahan intensitas pada serat optik, dengan cara ditetesi larutan amonia yang berbeda konsentrasi dan diukur dengan menggunakan OPM dan LS (1310 nm dan $1550 \mathrm{~nm}$ ) pada frekuensi $0 \mathrm{~Hz}, 270 \mathrm{~Hz}, 1000$ $\mathrm{Hz}$, dan $2000 \mathrm{~Hz}$.

OPM adalah alat yang digunakan untuk mengukur kekuatan dalam sinyal optik. Istilah ini biasanya mengacu pada perangkat untuk menguji daya rata-rata dalam sistem serat optik. Perangkat mengukur kekuatan cahaya biasanya disebut radiometers, fotometer, daya laser meter, pengukur cahaya atau lux meter.
Kadang-kadang meter daya optik digabungkan dengan fungsi tes yang berbeda seperti Optical Light Source (OLS) atau Visual Sesar Locator (VSL), atau mungkin sub-sistem dalam instrumen yang jauh lebih besar. Ketika dikombinasikan dengan sumber cahaya, instrumen biasanya disebut Rugi Optical Test Set [5].

Prosedur yang dilakukan pada penelitian ini terlihat pada flowchart yang ditunjukkan pada Gambar 3. Sensor amonia menggunakan kabel serat optik multimode dipotong sepanjang $14 \mathrm{~cm}$. Proses pemotongan menggunakan stripper pada bagian ujungnya. Dari potongan kabel serat optik sepanjang $14 \mathrm{~cm}$ tersebut, dibuka slongsongnya sepanjang $4 \mathrm{~cm}$ dibagian tengah. Proses ini disebut dengan proses uncladding. Proses uncladding serat optik dengan cara membuka jaket menggunakan stripper gigi pertama kemudian terdapat serabut yang dapat dipotong menggunakan cutter.

Selanjutnya terdapat coating, coating ini dikelupas dengan menggunakan stripper gigi kedua. Setelah coating terkelupas terlihat berwarna bening dengan lapisan buffer transparan. Untuk membuka lapisan buffer dapat menggunakan stripper gigi ketiga. Agar bagian tengah yang terkelupas, maka dilakukan dengan cara membuka sedikit demi sedikit dibagian ujungnya kemudian slongsong bagian tengah ditarik pelan-pelan keujung hingga bagian tengah sepanjang $4 \mathrm{~cm}$ tidak terdapat slongsong.

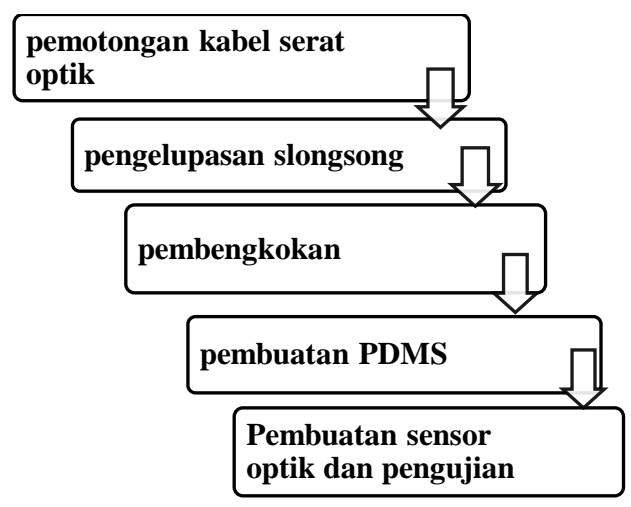

Gambar 3. Prosedur penelitian 
Bagian serat optik yang slongsongnya terbuka selanjutnya dibengkokkan secara manual dengan cara mendekatkan bagian tengah ke dekat api menggunakan lilin hingga serat optik melengkung dengan sendirinya. Selanjutnya mengarahkan bengkokan sesuai yang kita inginkan. Gambar 4 menunjukkan sketsa serat optik yang telah dibengkokkan. Membuat larutan PDMS dengan cara mencampurkan bahan PDMS dengan curing agent (pengering). PDMS ini berfungsi sebagai pengganti slongsong yang telah terkelupas. Membuat PDMS dengan perbandingan terhadap pengering 10:2. Dipanaskan pada temperatur $75^{\circ} \mathrm{C}$.

Pembuatan sensor serat optik sendiri dilakukan dengan menyiapkan serat optik yang sudah dikelupas selongsongnya dan sudah dibengkokkan pada bagian tengah juga sudah diselimuti larutan PDMS yang berfungsi untuk menggantikan slongsong pada bagian uncladding.

Menempelkan sampel serat optik ke PCB yang telah melalui proses etching menggunakan UV-glue pada bagian ujung uncladding. Selimuti serat optik pada bagian bawah lengkungan dengan PDMS tak berwarna, lakukan pembakaran pada hotplate pada temperature $75{ }^{\circ} \mathrm{C}$ hingga PDMS mengering (sekitar 3 jam). Setelah PDMS bagian bawah lengkungan mengering, selanjutnya pada bagian lengkungan selimuti dengan PDMS berwarna, melakukan pembakaran kembali hingga mengering.

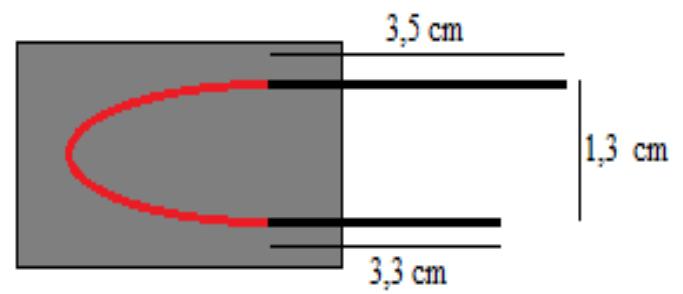

Gambar 4. Sketsa bending serat optic
Melakukan pengujian dengan menggunakan laser. Apakah cahaya akan keluar pada bagian kaki yang lain ketika kaki yang satunya disinari oleh laser. Ketika sinar laser keluar pada bagian kaki lainnya, maka langkah yang dilakukan selanjutnya yaitu menempelkan PCB berisi serat optik ke bagian ujung teflon dengan menggunakan solasi. Sambungkan kaki bagian satu ke OPM dan bagian lainnya ke LS dengan menggunakan kabel penghubung. Apabila intensitas cahaya sudah terbaca pada OPM berarti sambungan sudah berhasil.

\section{HASIL DAN PEMBAHASAN}

Hasil larutan PDMS dengan perbandingan 10:2 mengering setelah 3 jam pada temperatur $75^{\circ} \mathrm{C}$. Akhirnya peneliti menggunakan larutan tersebut. Gambar 5 menunjukkan PDMS yang sudah kering menyelimuti bagian uncladding sebagai pengganti slongsong.

Berdasarkan Tabel 1 ada sebuah pengaruh konsentrasi amonia terhadap besarnya intensitas cahaya. Apabila kita amati Gambar 6, pengaruh larutan amonia terhadap intensitas cahaya tidak stabil baik pada $\lambda=1310 \mathrm{~nm}$ maupun pada $\lambda=1550$ $\mathrm{nm}$.

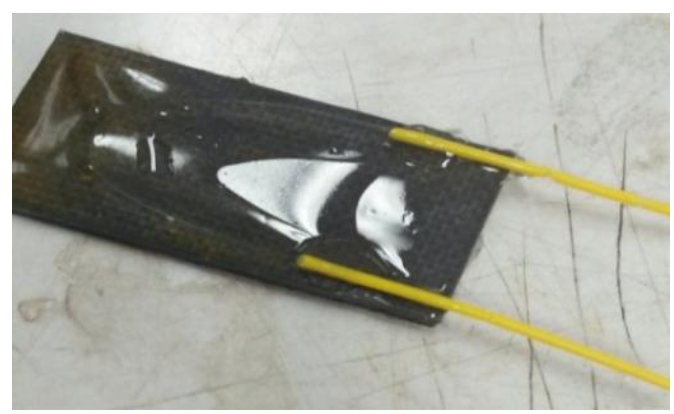

Gambar 5. Sampel sensor dilapisi PDMS 
Tabel 1. Hasil pengukuran

\begin{tabular}{|c|c|c|c|c|c|c|c|c|}
\hline \multirow{3}{*}{$\begin{array}{c}\text { Konsentrasi } \\
\text { Amonia } \\
(\%)\end{array}$} & \multicolumn{8}{|c|}{ Intensitas Cahaya (dBm) } \\
\hline & \multicolumn{2}{|c|}{$f=0 \mathrm{~Hz}$} & \multicolumn{2}{|c|}{$\mathrm{f}=270 \mathrm{~Hz}$} & \multicolumn{2}{|c|}{$\mathrm{f}=1000 \mathrm{~Hz}$} & \multicolumn{2}{|c|}{$\mathrm{f}=2000 \mathrm{~Hz}$} \\
\hline & 1310 & 1550 & 1310 & 1550 & 1310 & 1550 & 1310 & 1550 \\
\hline $1 \%$ & $-45,53$ & $-44,66$ & $-48,82$ & $-47,89$ & $-49,94$ & $-49,23$ & $-49,98$ & $-51,03$ \\
\hline $1,25 \%$ & $-43,84$ & $-42,4$ & $-47,18$ & $-42,7$ & $-47,55$ & $-47,54$ & $-48,03$ & $-49,57$ \\
\hline $2 \%$ & $-43,76$ & $-42,84$ & $-49,86$ & $-46,05$ & $-50,58$ & $-47,57$ & $-51,2$ & $-49,11$ \\
\hline $2,50 \%$ & $-43,24$ & $-42,78$ & $-47,1$ & $-45,85$ & $-48,12$ & $-47,45$ & $-49,15$ & $-49,02$ \\
\hline $3 \%$ & $-57,07$ & $-57,25$ & $-60,33$ & $-60,37$ & $-60,86$ & $-61,71$ & $-61,39$ & $-63,41$ \\
\hline $4 \%$ & $-52,1$ & $-48,17$ & $-55,31$ & $-52,57$ & $-55,83$ & $-53,4$ & $-56,27$ & $-54,84$ \\
\hline $5 \%$ & $-52,56$ & $-49,74$ & $-56,25$ & $-53,29$ & $-57,1$ & $-54,49$ & $-57,75$ & $-56,08$ \\
\hline $10 \%$ & $-52,05$ & $-48,54$ & $-55,39$ & $-52,06$ & $-56,06$ & $-53,17$ & $-56,79$ & $-54,73$ \\
\hline
\end{tabular}

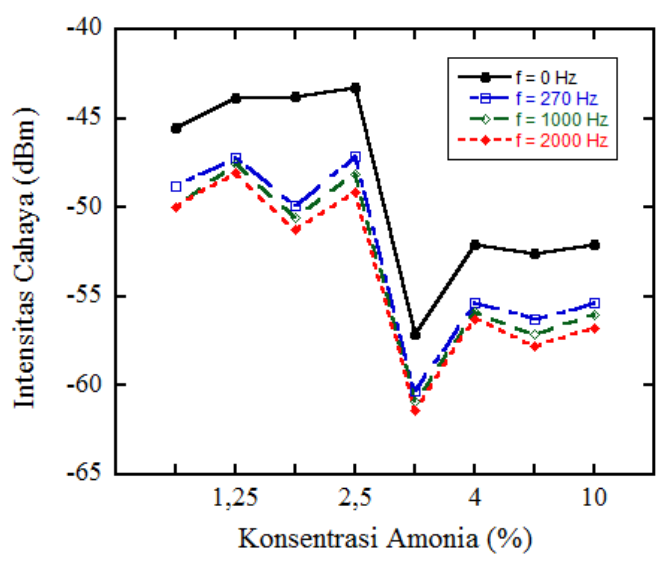

(a)

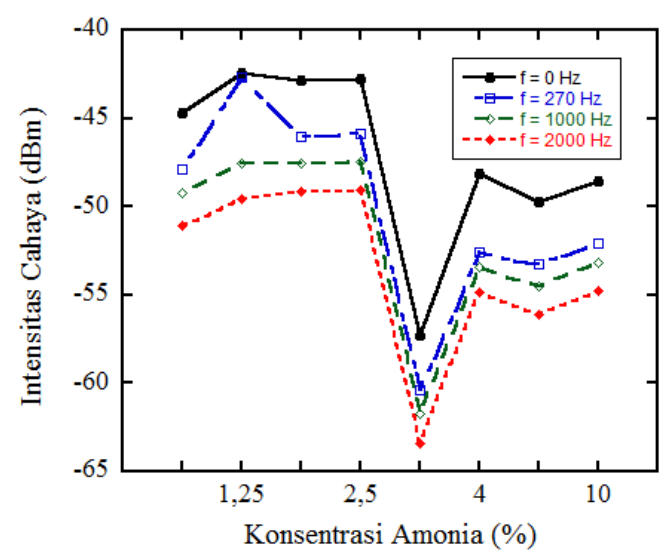

(b)

Gambar 6. Grafik hasil pengukuran ketika (a) $\lambda=1310 \mathrm{~nm}$ dan (b) $\lambda=1550 \mathrm{~nm}$

Selain karena lengkungan pada serat optik yang mengakibatkan adanya rugi-rugi juga bisa karena pengaruh dari peneliti atau faktor lingkungan. Sedangkan untuk pengaruh frekuensi terhadap intensitas cahaya berbanding terbalik. Ini artinya, semakin tinggi frekuensi cahaya maka semakin rendah intensitas cahayanya.

Multimode (MM) serat optik pada konsentrasi yang berbeda dari larutan amonia menunjukkan spektrum intensitas untuk berbagai konsentrasi amonia pada suhu kamar diperoleh dengan serat optik MM dilapisi PDMS.

\section{KESIMPULAN}

Sensor serat optik ini dapat digunakan untuk mengukur kadar amonia dan mempunyai karakteristik yang baik, yang ditunjukkan dengan adanya perubahan nilai loss yang berbeda-beda saat pengukuran dengan menggunakan OPM dengan konsentrasi larutan amonia yang berbeda. Hasil pengukuran sensor serat optik dengan menggunakan alat ukur dalam intensitas cahaya menunjukkan semakin tinggi frekuensi cahaya yang diberikan maka semakin rendah nilai intensitas cahaya dalam larutan amonia tersebut. 


\section{DAFTAR PUSTAKA}

[1] A. T. Indra and Harmadi, "Karakterisasi Sistem Sensor Serat Optik Berdasarkan Efek Gelombang Evanescent," J. Fis. Unand, vol. 3, no. 1, pp. 8-13, 2014.

[2] A. Hanafiah, "Teknologi serat optik," Staf Pengajar Dep. Tek. Elektro. Fak. Tek. USU, no. January 2006, pp. 8791, 2013.

[3] I.B.A. Pramarata, N. Wendri, "Rugirugi Serat Optik Berdasarkan Efek Gelombang Evanescent," Universitas Udayana.
[4] A. Ardi, A. N. Fauza, N. Syakir, and A. S. Kartasasmita, "Stabilitas Optik Polydimethylsiloxane ( PDMS ) Terhadap Paparan Sinar Ultraviolet," Mater. dan Energi Indones., vol. 08, no. 01, pp. 16-21, 2018.

[5] Anonim, "Optikal power meter," 2016. [Online]. Available: http://farrosaccessengineering.blogsp ot.com/2016/05/optical-power meter.html. [Accessed: 25-Feb2017]. 